\title{
Intensification of GVHD prophylaxis interferes with the effects of pretransplant herpes virus serology on the occurrence of grades II - IV acute graft-versus-host disease
}

\author{
J. W. Gratamai, 8, H. v. d. Nat ${ }^{6}$, H. T. Weiland ${ }^{2}$, T. Stijnen ${ }^{7}$, W. E. Fibbe ${ }^{3}$, J. M. J. J. Vossen ${ }^{4}$, R. Willemze ${ }^{3}$, \\ and L. F. Verdonck ${ }^{5}$ \\ Departments of ${ }^{1}$ Immunohematology and Blood Bank, ${ }^{2}$ Virology, ${ }^{3}$ Hematology, ${ }^{4}$ Pediatrics, University Hospital, Leiden, The Netherlands \\ ${ }^{5}$ Department of Hematology, University Hospital, Utrecht, The Netherlands \\ ${ }^{6}$ Laboratory of Virology, National Institute of Public Health and Environmental Protection, Bilthoven, The Netherlands \\ ${ }^{7}$ Department of Epidemiology and Biostatistics, Erasmus University, Rotterdam, The Netherlands \\ ${ }^{8}$ Department of Immunology, Daniel den Hoed Cancer Center, Rotterdam, The Netherlands
}

\begin{abstract}
Summary. The effects of pretransplant herpes virus serology on the occurrence of grades II-IV acute graftversus-host disease (GVHD) were studied in 262 recipients and their HLA-identical family donors. In 131 recipients on standard GVHD prophylaxis (either methotrexate or cyclosporin A) significant effects were observed for donor HSV serology (seropositivity associated with increased risk for GVHD) and donor EBV serology (seronegativity associated with increased risk). However, these effects were nonsignificant in the other 131 recipients on intensified GVHD prophylaxis (i.e., methotrexate combined with cyclosporin $\mathrm{A}$, in vivo anti-T-cell monoclonal antibodies, or various procedures to reduce the T-cell numbers in the transplants).
\end{abstract}

Key words: Bone marrow transplantation - Graftversus-host-disease - Herpes viruses

\section{Introduction}

The incidence and severity of acute graft-versus-host disease (GVHD) can be reduced by removing the bacterial microflora from the gastrointestinal tracts of animals [1] and human beings [11]. The potentiating effect of the gastrointestinal microflora on graft-versus-host reactivity may occur via the activation of lymphocytes or their precursors during the immediate post-transplant period. Similar effects may be mediated by viruses and parasites carried by the recipients at the time of transplantation [6]. Herpes viruses are important candidates since they establish life-long carrier status after initial infection and frequently reactivate during immunosuppression. In addition, herpes virus carrier status leads to the development of virus-specific humoral and cellular immunity, so

Address for correspondence: J. W. Gratama, Department of Immunology, Daniel den Hoed Cancer Center, P.O. Box 5201, NL-3008 AE Rotterdam, The Netherlands that the presence of virus-specific antibodies may be taken as a marker for carrier status and presence of virusspecific memory cells.

Several studies of the effects of pretransplant herpes virus serology in allogeneic bone marrow transplant (BMT) recipients and their donors on the development of acute GVHD have been performed (Table 1). Two singlecenter studies [2,7] were followed by a retrospective multicenter study of data collected by the European Group for Bone Marrow Transplantation [3]. In all studies, the risk of grades II - IV GVHD increased proportionally with the number of herpes viruses carried. However, results were discordant at the level of individual viruses (Table 1).

In 1986, the two BMT teams in Leiden intensified their GVHD prophylactic protocols to reduce GVHDrelated morbidity and mortality. Around the same time, the BMT team in Utrecht embarked on a protocol in which T-lymphocyte-depleted bone marrow grafts were reconstituted with a fixed low number of $\mathrm{T}$ cells prior to administration [10]. The present analysis of 262 patients who underwent transplantation by these three teams was performed to assess the effect of intensification of GVHD prophylaxis on the interaction between herpes virus carrier status and grades II-IV acute GVHD.

\section{Patients and methods}

Between 1978 and 1991, 262 patients received transplants with bone marrow grafts from their HLA-identical siblings in Leiden (Dept. of Hematology, $n=126$; Dept. of Pediatrics, $n=76$ ) and in Utrecht $(n=60)$. The diagnostic indications for BMT were severe aplastic anemia $(n=28)$, acute nonlymphoblastic leukemia $(n=120)$, acute lymphoblastic leukemia ( $n=50)$, chronic myelogenous leukemia $(n=35)$, non-Hodgkin's lymphoma $(n=9)$, Kahler's disease $(n=5)$, other hematological malignancies $(n=8)$ or other indications $(n=7)$. The median age of the patients was 35 years (range 10 months to 48 years). Standard GVHD prophylaxis (either methotrexate or cyclosporin A) was given to 131 patients. Intensified GVHD prophylaxis was given to the other 131 patients (methotrexate + cyclosporin $\mathrm{A}, n=21$; in vivo anti-T-cell monoclonal anti- 
Table 1. Pretransplant herpes virus serology and acute GVHD; summary of three clinical studies

\begin{tabular}{lllll}
\hline Lower risk & Higher risk & Leiden 1987 & Huddinge 1988 & EGBMT 1990 \\
\hline Donor & & & & \\
$0-2$ Viruses & $3-4$ Viruses & $p<0.05$ & $p<0.05$ & $p<0.05$ \\
HSV negative & HSV positive & $p<0.05$ & NS & NS \\
EBV positive & EBV negative & $p<0.05$ & NS & NS \\
Recipient & & & & \\
$0-2$ Viruses & $3-4$ Viruses & $p<0.05$ & $p<0.05$ & $p<0.05$ \\
CMV negative & CMV positive & NS & $p<0.05$ & NS \\
EBV negative & EBV positive & $p<0.05$ & NS & NS \\
\hline
\end{tabular}

bodies, $n=23$; in vitro T-cell depletion using anti-T-cell monoclonal antibodies, $n=28$; and fixed low T-cell numbers in the grafts, $n=60$ ). All transplants resulted in full engraftment. Four patients (three on standard and one on intensified GVHD prophylaxis) were excluded from subsequent analyses because they died without clinical signs of GVHD while being at risk for the disease (i.e., prior to day 100 post BMT).

IgG antibodies against herpes simplex virus (HSV), varicella zoster virus (VZV), and Epstein-Barr virus (EBV) capsid antigen were detected using indirect immunofluorescence assays, IgG antibodies against cytomegalovirus (CMV) late antigen by an enzymelinked immunoassay.

\section{Results}

Grades II-IV acute GVHD occurred in 53 of the 128 patients on standard GVHD prophylaxis $(41 \%)$ and in only $28 \%$ of the 130 patients on intensified GVHD prophylaxis $(22 \%)$. First, a multivariate analysis of the interaction between donor and recipient pretransplant herpes virus serology and acute GVHD was performed on all 262

Table 2. Multivariate analysis on 262 patients

A. Competing factors in the analysis

\begin{tabular}{lll}
\hline Pre-BMT serology & Odds ratio & $p$ value \\
\hline Intensified prophylaxis for GVHD & & \\
$\quad$ given & 0.20 & 0.0001 \\
Total GI decontamination & 0.24 & 0.01 \\
Increasing age, recipient & 1.0 & $\mathrm{NS}$ \\
Increasing age, donor & 1.0 & $\mathrm{NS}$ \\
Sex mismatch & 1.5 & $\mathrm{NS}$ \\
\hline
\end{tabular}

B. Pretransplant herpes virus serology

\begin{tabular}{lll}
\hline Pre-BMT serology & Odds ratio & $p$ value \\
\hline Donor & & \\
HSV positive & 2.8 & 0.03 \\
CMV positive & 1.6 & $\mathrm{NS}$ \\
VZV positive & 2.1 & $\mathrm{NS}$ \\
EBV positive & 0.3 & 0.01 \\
Recipient & & \\
HSV positive & 1.0 & $\mathrm{NS}$ \\
CMV positive & 1.5 & $\mathrm{NS}$ \\
VZV positive & 1.4 & $\mathrm{NS}$ \\
EBV positive & 2.6 & $\mathrm{NS}$ \\
\hline
\end{tabular}

patients. Competing nonvirological factors in the analysis were chosen on the basis of their significant role in previous analyses (Table 2, upper panel) $[5,7]$. With respect to herpes virus serology, significant but opposite effects were observed for donor HSV serology (higher risk vs. lower risk, seropositive vs. seronegative; $p=0.03$ ) and donor EBV serology (higher risk vs. lower risk, seronegative vs. seropositive; $p=0.01$ ) (Table 2, lower panel). Separate analysis of patients on standard and intensified GVHD prophylaxis revealed that the significant effects of donor HSV and EBV serology were confined to the patients on standard GVHD prohylaxis; the effects of herpes virus serology in the patients on intensified GVHD prophylaxis were nonsignificant (Table 3). Cross-tabulations for the individual viruses are shown in Table 4 (HSV, upper panel; EBV, lower panel) and illustrate the disappearance of the effect of donor HSV and EBV serology on acute GVHD. In both patient groups, grades II-IV acute GVHD are rare to absent in the (young) seronegative recipients of marrow from seronegative donors.

\section{Discussion}

We have shown that various protocols of intensified GVHD prophylaxis interfere with the effects of pretransplant herpes virus serology on the occurrence of grades II - IV acute GVHD. With respect to HSV, we have inferred that HSV-specific memory $T$ lymphocytes in the grafts are responsible for the effect [7]. This contention is supported by the observation of Boström et al. [4] that strong donor mononuclear cell reactivity to HSV is associated with an increased frequency of grades II-III GVHD. Thus, the activation of HSV-specific memory T lymphocytes by the HSV-encoded or cross-reactive antigens in the recipients may contribute to GVHD, possibly via the release of cytokines that induce systemic T-cell activation.

The first encounter of T lymphocytes from EBV-seronegative donors with the virus or with EBV-transformed cells leads to their polyclonal activation, as observed in infectious mononucleosis [9]. Indeed, an increased rate of EBV production in the oropharynx has been observed in the immediate post-BMT period [8], similar to the situation in immunosuppressed renal transplant recipients [12]. Again, the depletion or the functional suppression of T lymphocytes would prevent their activation and cytokine production. 
Table 3. Effect of intensification of GVHD prophylaxis

Table 4. Effects of intensification of GVHD prophylaxis

\begin{tabular}{llllll}
\hline Pre-BMT serology & \multicolumn{2}{l}{ Standard } & & \multicolumn{2}{l}{ Intensified } \\
\cline { 2 - 3 } & O.R. & $p$ value & & O.R. & $p$ value \\
\hline Donor & & & & \\
HSV positive & 5.4 & 0.007 & & 1.2 & $\mathrm{NS}$ \\
CMV positive & 3.4 & 0.03 & & 1.1 & $\mathrm{NS}$ \\
VZV positive & 2.2 & $\mathrm{NS}$ & & 2.1 & $\mathrm{NS}$ \\
EBV positive & 0.08 & 0.002 & & 0.8 & $\mathrm{NS}$ \\
Recipient & & & & \\
HSV positive & 2.6 & $\mathrm{NS}$ & & 0.7 & $\mathrm{NS}$ \\
CMV positive & 1.1 & $\mathrm{NS}$ & & 1.9 & $\mathrm{NS}$ \\
VZV positive & 2.0 & $\mathrm{NS}$ & 1.1 & $\mathrm{NS}$ \\
EBV positive & 6.0 & 0.05 & 1.1 & $\mathrm{NS}$ \\
\hline
\end{tabular}

A. Pretransplant HSV serology and acute GVHD

\begin{tabular}{|c|c|c|c|c|c|}
\hline \multicolumn{2}{|c|}{ Pre-BMT serology } & \multicolumn{2}{|l|}{ Standard } & \multicolumn{2}{|c|}{ Intensified } \\
\hline Recipient & Donor & Gr. $0-\mathrm{I}$ & Gr. II - IV & Gr. $0-I$ & Gr. II -IV \\
\hline Negative & Negative & 11 & $1(8 \%)$ & 12 & $0 \quad(0 \%)$ \\
\hline Negative & Positive & 10 & $2(17 \%)$ & 7 & $4(36 \%)$ \\
\hline Positive & Negative & 19 & $5(21 \%)$ & 10 & $6(38 \%)$ \\
\hline Positive & Positive & 35 & $45(56 \%)$ & 73 & $18(20 \%)$ \\
\hline
\end{tabular}

B. Pretransplant EBV serology and acute GVHD

\begin{tabular}{|c|c|c|c|c|c|}
\hline \multicolumn{2}{|c|}{ Pre-BMT serology } & \multicolumn{2}{|l|}{ Standard } & \multicolumn{2}{|c|}{ Intensified } \\
\hline Recipient & Donor & Gr. 0-I & Gr. II-IV & Gr. 0-I & Gr. II-IV \\
\hline Negative & Negative & 11 & $2(15 \%)$ & 4 & $0 \quad(0 \%)$ \\
\hline Negative & Positive & 9 & $1(10 \%)$ & 6 & $2(25 \%)$ \\
\hline Positive & Negative & 4 & $10(71 \%)$ & 6 & $2(25 \%)$ \\
\hline Positive & Positive & 51 & $40(44 \%)$ & 86 & $24(22 \%)$ \\
\hline
\end{tabular}

T lymphocytes constitute the final common pathway through which GVHD is effectuated. This study shows that the depletion of $\mathrm{T}$ lymphocytes from the marrow grafts or the prevention of their activation post BMT abolishes the significance of pretransplant herpes virus serology as a risk factor for grades II-IV acute GVHD.

\section{References}

1. Bekkum DW Van, Roodenburg J, Heidt PJ, Van der Waaij D (1976) Mitigation of secondary disease of allogeneic mouse radiation chimeras by modification of the intestinal microflora. JNCI 52: 401-404

2. Boström L, Ringdén O, Sundberg B, Linde A, Tollemar J, Nilsson B (1988) Pretransplant herpes virus serology and acute graftversus-host disease. Transplantation 46: $548-552$

3. Boström L, Ringdén O, Gratama JW, Jacobsen N, Prentice HG, Zwaan FE, Nilsson B, for the Leukemia Working Party of the European Group for Bone Marrow Transplantation (1990) A role of herpes virus load for the development of acute graftversus-host disease. Bone Marrow Transplant 5: 321-326

4. Boström L, Ringdén O, Forsgren M (1991) Strong donor leukocyte reactivity for herpes simplex virus (HSV) antigen in HSVimmune donors, combined with recipient seropositivity for
HSV, is associated with acute graft-versus-host disease. Scand J Immunol (in press)

5. Gale RP, Bortin MM, Van Bekkum DW, et al. (1987) Risk factors for acute graft-versus-host disease. $\mathrm{Br} \mathrm{J}$ Haematol 67: $397-406$

6. Gast GC De, Gratama JW, Ringdén O, Gluckman E (1987) The multifactorial etiology of graft-versus-host disease. Immunol Today 8:209-212

7. Gratama JW, Zwaan FE, Stijnen T, et al. (1987) Herpes virus immunity and acute graft-versus-host disease. Lancet 1: $471-474$

8. Gratama JW, Lennette ET, Lönnqvist B, et al. (1992) Detection of multiple Epstein-Barr viral strains in allogeneic bone marrow transplant recipients. J Med Virol (in press)

9. Svedmyr EI, Ernberg J, Seeley O et al. (1984) Virologic, immunologic and clinical observations on a patient during the incubation, acute, and convalescent phases of infectious mononucleosis. Clin Immunol Immunopathol 30: 437-450

10. Verdonck LF, Gast GC De, Van Heugten HG, Dekker AW (1990) A fixed low number of T cells in HLA-identical allogeneic bone marrow transplantation. Blood 75: 776-780

11. Vossen JM, Heidt PJ (1990) Gnotobiotic measures for the prevention of acute graft-versus-host disease. In: Burakoff, Deeg, Ferrara, Atkinson (eds) Graft-versus-host disease, chap 21. Marcel Dekker, New York

12. Yao QY, Rickinson AB, Gaston JSH, Epstein MA (1985) In vitro analysis of the Epstein-Barr virus: host balance in longterm renal allograft recipients. Int $\mathbf{J}$ Cancer 35: 43-49 